\title{
EFFECT OF SUBCHRONIC EXPOSURE TO CHROMIUM ON HEMATOLOGICAL AND BIOCHEMICAL PARAMETERS OF MALE ALBINO RAT
}

\author{
Jahnabi Saha ${ }^{1}$, Soma Choudhuri ${ }^{2}$, Dipayan Choudhuri ${ }^{1 *}$ \\ ${ }^{1}$ Department of Human Physiology, Endocrinology and Reproductive Physiology Laboratory, Tripura University (A Central \\ University), Agartala -799022, Tripura, India ${ }^{2}$ Department of Physiology, Tripura Medical College and Br. B.R. Ambedkar Teaching \\ Hospital, Agartala - 799014, Tripura, India. Email: dipayanchoudhuri@gmail.com
}

Received: 02 February 2017, Revised and Accepted: 28 February 2017

ABSTRACT

Objectives: Exposure to chromium, the transition element found in many compounds of earth's crust, leads to various health hazards including cancer, dermatitis, damage of liver and kidneys, and reproductive toxicity in both male and female. Toxic effect of chronic exposure to chromium at low environmentally relevant dose is recently recognized and less studied. In the present study, we evaluated the effect of subchronic exposure to low doses of chromium VI $\left(\mathrm{K}_{2} \mathrm{Cr}_{2} \mathrm{O}_{7}\right)$ on various hematological and biochemical parameters in male albino rats.

Methods: Male albino rats $\left(160 \pm 10\right.$ g) received $1 / 25,1 / 50$, and $1 / 100$ of reported oral $\mathrm{LD}_{50}$ dose of chromium $\mathrm{VI}\left(\mathrm{K}_{2} \mathrm{Cr} \mathrm{O}_{7}\right)$ for 90 consecutive days. After treatment, the blood was collected for analysis of various hematological and biochemical parameters.

Results: Exposure to chromium VI at $1 / 25 \mathrm{LD}_{50}$ dose caused decrease in body weight gain and reduction in the weight of the reproductive organs along with increase in the weight of the liver and kidney. Numbers of red blood cells, white blood cells, platelets, and hemoglobin concentration reduced with increase in clotting time. The total sperm count and motility was also reduced in exposed rats. There was a decrease in plasma protein and albumin concentration, with increase in plasma glucose and cholesterol level. The activity of enzyme alanine aminotransferase and enzyme aspartate aminotransferase was stimulated in treated rats.

Conclusion: The results of the present study revealed that chronic low-dose exposure to chromium VI resulted in a toxic effect in experimental male albino rats.

Keywords: Chromium VI $\left(\mathrm{K}_{2} \mathrm{Cr}_{2} \mathrm{O}_{7}\right)$, Hematological parameters, Biochemical parameters.

(C) 2017 The Authors. Published by Innovare Academic Sciences Pvt Ltd. This is an open access article under the CC BY license (http://creativecommons. org/licenses/by/4. 0/) DOI: http://dx.doi.org/10.22159/ajpcr.2017.v10i5.17468

\section{INTRODUCTION}

Chromium is one of the major environmental toxicants that affect human health. It is one among the eight most common pollutant heavy metals listed by the Environmental Protection Agency [1]. It is a naturally occurring element found in rocks, volcanic dust and gasses, soils as well as plants and animals. This transition metal can exist in various oxidized forms ranging from -2 to +6 . The three main oxidation forms of chromium, commonly found in the workplace and general environment, are chromium (0), chromium (III), and chromium (VI). Chromium (0) is the metal chromium, a steel-gray solid with a high melting point usually used for making steel and other alloys. Chromium (III) and chromium (VI) compounds are widely used industrially in stainless steel production, welding, electroplating, leather tanning, production of dyes and pigments, and wood preservatives [2,3]. It is well known that oral intake along with food and water is the major route of exposure to chromium for the general population. It has been reported that the chromium (VI) form appears to be 10-100 times more toxic than the chromium (III) form when both are administered by the oral route [4]. Chromium (VI) can easily enter the cell than chromium (III) through $\mathrm{SO}_{4}{ }^{2-}$ and $\mathrm{PO}_{4}{ }^{2-}$ channels. After entering the cell, chromium (VI) undergoes a chain reaction with production of chromium intermediates such as chromium (V) and chromium (IV) by cellular reductants such as ascorbic acid and riboflavin, glutathione, and serum protein [5]. The reduced product binds to intracellular proteins, resulting in an elevation of total chromium in the blood cell for several weeks. During this reduction process, chromium produces reactive oxygen species and generates oxidative stress. This in turn is responsible for defective hematopoiesis [6]. It has been reported that chromium (VI) is considered as a toxic transition heavy metal and a potent industrial hazard that causes severe damage to a variety of tissues and organs including the reproductive system [7-10]. Most of the studies on toxic effects of chromium involve a dose much higher than the amount of chromium available in drinking water and within the permissible limit set by the World Health Organization [11]. The effect of subchronic exposure to chromium at low environmentally relevant dose level is not well established. Therefore, in the present study, we investigated the effect of chronic exposure to chromium in low concentration on various hematological and biochemical parameters in male albino rats.

\section{METHODS}

\section{Chemicals and drugs}

Potassium dichromate $\left(\mathrm{K}_{2} \mathrm{Cr}_{2} \mathrm{O}_{7}\right)$ was purchased from Merck Specialities Pvt. Ltd., Mumbai, India. Magnesium chloride, sodium hydroxide, sodium p-nitrophenol, citric acid, and sodium citrate were obtained from Sisco Research Laboratories Pvt. Ltd. The commercial kits such as glucose kit, total cholesterol kit, urea kit, creatinine kit, total protein kit, albumin kit, enzyme alanine aminotransferase kit, and aspartate aminotransferase kit were purchased from Coral Clinical System, India.

\section{Animals}

Twenty-four adult male Wistar rats (70 \pm 10 days) weighing $170 \pm 10 \mathrm{~g}$ were used in the present study. The animals were housed in polypropylene cages in the institutional animal house under controlled condition of temperature $\left(25 \pm 2^{\circ} \mathrm{C}\right)$ and normal day/night schedule (12 L:12 D). Animals were fed on standardized normal diet which consists of wheat and gram in 1:1 ratio, salt, sugar, milk, and water ad libitum. The entire study protocol was approved by the Institutional Animal Ethical Committee (IAEC). 
Study design

The rats are equally divided into four groups consisting of six rats per group. The animals of different groups received treatment orally through gavages for 90 days as follows:

- Group I - Control group - Distilled water $2 \mathrm{ml} /$ day.

- Group II - Treated Group I - $\mathrm{K}_{2} \mathrm{Cr}_{2} \mathrm{O}_{7}-0.25 \mathrm{mg} / \mathrm{kg}$ bw/day.

- Group III - Treated Group II - $\mathrm{K}_{2} \mathrm{Cr}_{2} \mathrm{O}_{7}-0.5 \mathrm{mg} / \mathrm{kg}$ bw/day

- Group IV - Treated Group III - $\mathrm{K}_{2} \mathrm{Cr}_{2} \mathrm{O}_{7}-1 \mathrm{mg} / \mathrm{kg}$ bw/day.

The doses of the drug were determined according to the median value of reported oral $\mathrm{LD}_{50}$ dose [12].

\section{Animal sacrifice}

At the end of treatment period, animals were sacrificed by cervical dislocation following ether anesthesia. Utmost care was taken during the time of sacrifice according to the Indian Council of Medical Research guidelines [13]

\section{Body weight and organ weight}

The body weight was recorded on the first day of treatment (initial), on the interval of every 15 days, and on the day of sacrifice (final). The liver, kidney, testicles, and accessory sex organs, namely, seminal vesicles, ventral prostate, and cauda epididymis were dissected out and trimmed of the attached tissues and weighed. The relative weight of organs was expressed per $100 \mathrm{~g}$ of body weight to ensure normalization of data for statistical analysis.

\section{Hematological studies}

The fresh blood was collected in heparinized test tubes; some of the blood was centrifuged at $3000 \mathrm{rpm}$ to obtain the serum, which was kept frozen at $-20^{\circ} \mathrm{C}$ until used for further analysis.

The other blood was used to determine the hematological parameters such as hemoglobin concentration, red blood cell (RBC) count, white blood cell (WBC) count, platelet count, and clotting time using the standard procedures

\section{Biochemical studies from serum}

The serum glucose was measured by the glucose oxidaseperoxidase/peroxidase oxidase-peroxidase method. The serum cholesterol was measured by the cholesterol oxidase/peroxidase aminophena method. The serum urea was measured by the modified Berthelot method. The serum creatinine was measured by the modified Jaffe's Kinetic method. The serum protein was measured by the biuret method. The serum albumin was measured by the bromocresol green method. The serum glutamic pyruvic transaminase and serum glutamic oxaloacetic transaminase were measured by Reitman and Frankel method.

\section{Sperm count and sperm motility}

Sperm samples were collected from the cauda epididymis. Sperm count and motility was determined by hemocytometer following the method of Majumder and Biswas [14]. These two parameters were expressed as a percentage of total sperms.

\section{Data analysis}

Data were analyzed using statistical software StatPro for Windows, version 11.0. Mean and SE values for each parameters in different groups were calculated. A post hoct-test was performed to compare the differences between means. A statistically significance value was set at $p<0.05$.

\section{RESULTS}

\section{Effect on body weight}

Table 1 represents percentage gain of body weight and relative organ weight in control and different treatment groups. The body weight gain reduced significantly in treatment Group III.

\section{Effect on organ weight}

There was a significant increase in the weight of the liver and kidney in treated animals. Weight of the heart and spleen varied insignificantly between the groups. There was a decrease in relative weight of testes and epididymis and increase in the weight of other accessory organs after treatment with potassium dichromate for 90 days in treatment Group III (Table 1).

\section{Effect on hematological parameters}

Hematological study showed a significant decrease in hemoglobin concentration along with increase in counts of $\mathrm{RBC}, \mathrm{WBC}$, and platelet in animals of treatment Group III. The clotting time increased significantly in animals of this group (Table 2).

\section{Effect on biochemical parameters}

Biochemical analysis represented in Table 3 showed a significant decrease in plasma protein and albumin level in chromium-treated animals. Plasma glucose, cholesterol, urea, creatinine, enzyme alanine aminotransferase, and aspartate aminotransferase increased significantly in animals of treatment Group III.

Table 1: Change in body weight and organ weight in male rats following exposure to chromium for 90 days

\begin{tabular}{lllc}
\hline Parameter & $\begin{array}{l}\text { Control } \\
\text { group (6) }\end{array}$ & Treatment Group I (6) & Treatment Group II (6) \\
& Treatment Group III (6) \\
\hline Body weight gain (\%) & $44.82 \pm 1.58$ & $42.86 \pm 1.75$ & $41.69 \pm 1.37$ \\
Weight of liver (g/100 bw) & $4.39 \pm 0.08$ & $4.38 \pm 0.08$ & $4.42 \pm 0.07$ \\
Weight of kidney (g/100 bw) & $1.46 \pm 0.05$ & $1.46 \pm 0.03$ & $1.50 \pm 0.03$ \\
Weight of heart (g/100 bw) & $0.59 \pm 0.01$ & $0.60 \pm 0.07$ & $0.57 \pm 0.01$ \\
Weight of spleen (g/100 bw) & $1.24 \pm 0.07$ & $1.30 \pm 0.02$ & $1.29 \pm 0.16$ \\
Weight of testes (g/100 bw) & $1.33 \pm 0.02$ & $1.31 \pm 0.02$ & $1.27 \pm 0.06$ \\
Weight of epididymis (mg/100 bw) & $165.87 \pm 1.17$ & $161.53 \pm 2.09$ & $160.66 \pm 2.46$ \\
Weight of seminal vesicles (mg/100 bw) & $170.35 \pm 3.09$ & $164.48 \pm 3.34$ & $162.18 \pm 4.20$ \\
Weight of prostate (mg/100 bw) & $63.23 \pm 1.77$ & $60.46 \pm 2.18$ & $1.0 .10 \pm 0.06$ \\
Weight of bulbourethral gland (mg/100 bw) & $207.93 \pm 4.67$ & $199.08 \pm 6.33$ & $1.02 \pm 0.06^{*}$ \\
\hline
\end{tabular}

Values are in mean \pm SE. Number in parenthesis indicates number of animal in each group. ${ }^{*} \mathrm{p}<0.05$

Table 2: Effect of treatment with hexavalent chromium on hematological parameters of the animal

\begin{tabular}{|c|c|c|c|c|c|}
\hline Animal (6) & $\mathrm{Hb}(\mathrm{g} / \mathrm{dl})$ & RBC count $\left(10^{6} / \mu \mathrm{l}\right)$ & WBC count $\left(10^{3} / \mu \mathrm{l}\right)$ & Platelet count $\left(10^{3} / \mu \mathrm{l}\right)$ & Clotting time (min) \\
\hline Control group (6) & $13.48 \pm 0.23$ & $6.07 \pm 0.06$ & $7.95 \pm 0.16$ & $743.99 \pm 8.09$ & $5.05 \pm 0.03$ \\
\hline Treatment Group I (6) & $13.37 \pm 0.28$ & $5.87 \pm 0.12$ & $7.48 \pm 0.28$ & $694.11 \pm 22.28$ & $5.38 \pm 0.18$ \\
\hline Treatment Group II (6) & $12.90 \pm 0.15$ & $5.73 \pm 0.05$ & $7.37 \pm 0.23$ & $678.76 \pm 24.13$ & $5.45 \pm 0.15$ \\
\hline Treatment Group III (6) & $9.80 \pm 0.01 *$ & $3.80 \pm 0.01^{*}$ & $4.60 \pm 0.01^{*}$ & $554.69 \pm 0.01 *$ & $7.95 \pm 0.01^{*}$ \\
\hline
\end{tabular}

Values are in mean \pm SE. Number in parenthesis indicates number of animal in each group. ${ }^{*} \mathrm{p}<0.05$, RBC: Red blood cell, WBC: White blood cell 
Table 3: Serum biochemical profile of male rats following daily exposure to hexavalent chromium for 90 days

\begin{tabular}{|c|c|c|c|c|}
\hline Parameters & Control group & Treatment Group I & Treatment Group II & Treatment Group III \\
\hline Plasma protein (g/dl) & $7.59 \pm 0.08$ & $7.44 \pm 0.11$ & $7.29 \pm 0.10$ & $6.39 \pm 0.01^{*}$ \\
\hline Plasma albumin (g/dl) & $4.19 \pm 0.03$ & $4.09 \pm 0.05$ & $4.07 \pm 0.04$ & $3.23 \pm 0.09^{*}$ \\
\hline Plasma glucose (mg/dl) & $63.62 \pm 1.16$ & $65.22 \pm 1.35$ & $66.08 \pm 1.05$ & $78.56 \pm 0.01 *$ \\
\hline Plasma cholesterol (mg/dl) & $37.97 \pm 0.61$ & $39.55 \pm 0.99$ & $40.66 \pm 0.80$ & $48.72 \pm 0.01 *$ \\
\hline Plasma urea $(\mathrm{mg} / \mathrm{dl})$ & $17.80 \pm 0.26$ & $18.78 \pm 0.55$ & $19.14 \pm 0.46$ & $23.64 \pm 0.09 *$ \\
\hline Plasma creatinine $(\mathrm{mg} / \mathrm{dl})$ & $1.30 \pm 0.08$ & $1.39 \pm 0.09$ & $1.48 \pm 0.10$ & $2.16 \pm 0.08^{*}$ \\
\hline Alanine aminotransferase (units/ml) & $9.03 \pm 0.14$ & $9.53 \pm 0.16$ & $9.56 \pm 0.17$ & $13.11 \pm 0.01 *$ \\
\hline Aspartate aminotransferase (units/ml) & $8.69 \pm 0.04$ & $9.02 \pm 0.25$ & $9.14 \pm 0.16$ & $10.26 \pm 0.01^{*}$ \\
\hline
\end{tabular}

Values are mean \pm SE. Number in parenthesis indicates number of animal in each group. ${ }^{*} \mathrm{p}<0.05$

Table 4: Epididymal sperm count and motility study after exposure to hexavalent chromium

\begin{tabular}{llll}
\hline Parameter & $\begin{array}{l}\text { Control } \\
\text { group (6) }\end{array}$ & Treatment Group I (6) & Treatment Group II (6) \\
& Treatment Group III (6) \\
\hline Sperm count (million cells/cauda epididymis) & $141.72 \pm 4.89$ & $145.76 \pm 3.08$ & $134.80 \pm 1.80$ \\
Sperm motility (\%) & $75.05 \pm 0.79$ & $73.49 \pm 1.49$ & $71.72 \pm 0.70$ \\
\hline
\end{tabular}

Values are mean \pm SE. Number in parenthesis indicates number of animal in each group. ${ }^{*} \mathrm{p}<0.05$

\section{Effect on sperm count and motility}

There was a significant decrease in sperm count and motility in treatment Group III after potassium dichromate treatment in male rats (Table 4).

\section{DISCUSSION}

The effect of chronic exposure to potassium dichromate on body weight gain and on the weight of the vital organs liver and kidney, in our study, revealed that there was a significant decrease in body weight gain at highest dose along with an increase in relative weights of the liver and kidney. This indicated that chronic treatment with potassium dichromate resulted in a general toxic effect in the animals. The increase in the weight of the liver and kidney coupled with decrease in body weight gain due to chronic exposure to chromium at low-dose level indicates general toxic effect of such exposure on male rats [15]. This suggested that chronic chromium exposure resulted in a nutritional disturbance in treated rats [16]. Chandra et al. observed similar decline in body weight gain after exposure to potassium dichromate for 26 days [17].

From our observation, it can be seen that treatment with potassium dichromate induces anemia type of condition with decreased RBC count and hemoglobin concentration. Earlier reports revealed that chromium exposure to rats resulted in reduction of RBC count and hematocrit value along with a decrease in hemoglobin concentration. The decrease in hemoglobin appears to be due to inhibition of its biosynthesis by decreasing the succinyl pool as well as glycine pool [18]. In this study, along with decreased RBC count, there was also decrease in WBC and platelet count. This might due to generalized injury caused to the hematopoietic stem cells by chromium treatment [19]. Similar disruption in hemopoietic mechanisms was observed by Adjroud after potassium dichromate exposure in both male and female rats [20].

The biochemical analysis in this study showed an increase in activities of enzymes alanine aminotransferase, enzyme aspartate aminotransferase, creatinine, and urea nitrogen level with a decline in protein and albumin levels. This indicated general and systemic toxic effect of heavy metals on male rats [21]. Increase in plasma glucose and cholesterol level in this study might be due to less utilization of these nutrients at tissue level [22].

The results of the study revealed that chronic treatment of potassium dichromate for 90 days at a dose three times to $1 / 50$ of $\mathrm{LD}_{50}$ dose resulted in decrease in the weight of testes and epididymis and increase in the weight of prostate and seminal vesicles in male rats. Similar observation on the effect of hexavalent chromium on male reproductive system has been reported by several authors. Marouani et al. observed a similar effect on reproductive organs of male rats after intraperitoneal injection of potassium dichromate ( 1 or $2 \mathrm{mg} / \mathrm{kg} \mathrm{bw}$ ) for 15 consecutive days [23]. Chandra et al. observed uniform decline in weight of testes and other accessory male sex organs after chromium (VI) treatment in male rats [17]. These observations are corroborated with a decrease in number and motility of sperm in this study.

\section{CONCLUSION}

The study revealed that low subchronic treatment with potassium dichromate (Chromium VI) resulted in general toxicity in male albino rats.

\section{ACKNOWLEDGMENT}

The author would like to thank State Biotech Hub, Department of Human Physiology, Tripura University, Agartala, India.

\section{REFERENCES}

1. Gupta S, Singh S, Sharma S. Tolerance against heavy metal toxicity in cyenobacteria: Role of antioxidant defence system. Int J Pharm Pharm Sci 2015;7(2):9-16.

2. Agency for Toxic Substances and Disease Registry (ATSDR). Toxicological Profile for Chromium. Atlanta: U. S. Department of Health and Human Services; 2000.

3. Ahmed MN, Chandrasekharan N, Mukharjee A. Biochemical analysis of tannery effluent. Int J Pharm Pharm Sci 2014;6:644-5.

4. Zhitkovich A. Importance of chromium-DNA adducts in mutagenicity and toxicity of chromium(VI). Chem Res Toxicol 2005;18(1):3-11.

5. Valko M, Rhodes CJ, Moncol J, Izakovic M, Mazur M. Free radicals, metals and antioxidants in oxidative stress-induced cancer. Chem Biol Interact 2006;160(1):1-40.

6. Manerikar RS, Apte AA, Ghole VS. In vitro and in vivo genotoxicity assessment of Cr (VI) using comet assay in earthworm coelomocytes. Environ Toxicol Pharmacol 2008;25(1):63-8.

7. Andersson MA, Petersson Grawé KV, Karlsson OM, AbramssonZetterberg LA, Hellman BE. Evaluation of the potential genotoxicity of chromium picolinate in mammalian cells in vivo and in vitro. Food Chem Toxicol 2007;45(7):1097-106

8. Banu SK, Samuel JB, Arosh JA, Burghardt RC, Aruldhas MM. Lactational exposure to hexavalent chromium delays puberty by impairing ovarian development, steroidogenesis and pituitary hormone synthesis in developing Wistar rats. Toxicol Appl Pharmacol 2008;232(2):180-9.

9. Helena O, Marcello S, Migual AG, Teresa MS, Pereira Mde L. Evaluation of in vivo reproductive toxicity of potassium dichromate in male mice. Exp Toxicol Pathol 2010;62(4):391-404.

10. Samuel JB, Stanley JA, Vengatesh G, Princess RA, Muthusami S, 
Roopha DP, et al. Ameliorative effect of vitamin $\mathrm{C}$ on hexavalent chromium - Induced delay in sexual maturation and oxidative stress in developing wistar rat ovary and uterus. Toxicol Ind Health 2012;28(8):720-30.

11. Li H, Chen Q, Li S, Yao W, Li L, Shi X, et al. Effect of Cr(VI) exposure on sperm quality: Human and animal studies. Ann Occup Hyg 2001:45(7):505-11.

12. WHO. Guidelines for Drinking-Water Quality. Geneva, Switzerland: World Health Organization; 2003.

13. Approved Guidelines by Committee for the Purpose of Control and Supervision of Experiments on Animals (CPCSEA) on the Norms and Practices for Regulation of Animal Experimentation. ICMR Guidelines; 2006.

14. Majumder GC, Biswas R. Evidence for the occurrence of an ecto(adenosine triphosphatase) in rat epididymal spermatozoa. Biochem J 1979;183(3):737-43.

15. Jadhav SH, Sarkar SN, Patil RD, Tripathi HC. Effects of subchronic exposure via drinking water to a mixture of eight water-contaminating metals: A biochemical and histopathological study in male rats. Arch Environ Contam Toxicol 2007;53(4):667-77.

16. Ibrahim NM, Eweis EA, El-Beltagi HS, Abdel-Mobdy YE. Effect of lead acetate toxicity on experimental male albino rat. Asian Pac J Trop Biomed 2012;2(1):41-6.
17. Chandra AK, Chatterjee A, Ghosh R, Sarkar M. Vitamin E supplementation protect chromium (VI) - Induced spermatogenesis and steroidogenic disorders in testicular tissues of rats. Food Chem Toxicol 2010;48(3):972-9

18. Kim HY, Lee SB, Jang BS. Subchronic inhalation toxicity of soluble hexavalent chromium trioxide in rats. Arch Toxicol 2004;78(7):363-8.

19. Shrivastava R, Srivastava S, Upreti RK, Chaturvedi UC. Effects of dengue virus infection on peripheral blood cells of mice exposed to hexavalent chromium with drinking water. Indian J Med Res 2005;122(2):111-9.

20. Adjroud O. Effects of potassium dichromate on haematological parameters in female and male wistar albino rats. Assiut Univ Bull Environ Res 2009;12(2):87-99.

21. Balakrishnan R, Kumar CS, Rani MU, Kavita K, Boobalan G, Reddy AG. Evaluation of protective action of a-tocopherol in chromium-induced oxidative stress in female reproductive system of rats. J Nat Sci Biol Med 2013;4(1):87-93

22. Yousif AS, Ahmed AA. Effects of cadmium $(\mathrm{Cd})$ and lead $(\mathrm{Pb})$ on the structure and function of thyroid gland. Afr J Environ Sci Technol 2009;3(3):78-85

23. Marouani N, Tebourbi O, Mahjoub S, Yacoubi MT, Sakly M, Benkhalifa $\mathrm{M}$, et al. Effects of hexavalent chromium on reproductive function of male adult rats. Reprod Biol 2012;12(2):119-33. 